\title{
Evaluation of the Application of Wastewater and Bioventing System for the Treatment of Crude Oil Contaminated Soils
}

\author{
Ifeanyi M. S. Anekwe and Yusuf. M. Isa
}

\begin{abstract}
Environmental pollution is a form of land degradation which has contributed immensely to the reduction of available arable lands and could lead to the total annihilation of the ecosystem if not effectively mitigated. Bioremediation technology offers a biological means which provide an eco-friendly and cost-effective approach for soil remediation in contrast to physicochemical methods. This study aims to evaluate the application of wastewaters and air-injection for the treatment of crude oil contaminated soils. The treatment involves the amendment of crude oil contaminated soils with wastewaters at different ratios and the injection of atmospheric air. The results showed that the combined application of wastewater and air-injection was effective with $60-75 \%$ TPH removal efficiency while single application recorded $48-59 \%$ and $55 \%$ for wastewater and air-injection respectively. The study showed that the application of wastewater and air-injection can serve as a promising strategy for the remediation of crude oil contaminated soils.
\end{abstract}

Keywords - Biostimulation, Bioventing, Crude oil contaminated soils, Wastewater.

\section{INTRODUCTION}

The presence of undesirable (toxic) substances in the environment in high concentration is subject to environmental pollution and ecological imbalance which has contributed to the gradual degradation of terrestrial and aquatic habitat. This release of these toxic substances can be attributed to industrial activities such as the mineral exploration and processing of crude oil. Crude oil is an essential raw material required to produce petroleum-based products such as premium motor spirit (PMS), dual-purpose kerosene (DPK) and automated gas oil (AGO) among other products that serve as a source of energy for industry and daily life. Soil or water contamination by crude oil can be attributed to oil spills from oil rig blow-out during drilling operations as a result of pressure control system failure and also from tankers or refineries during transportation or processing of crude oil respectively.

Manuscript received October 5, 2020. This work was supported by Durban University of Technology Research Funds

I. M. S. Anekwe is with the Chemical Engineering Department, Durban University of Technology, Durban 4000, South Africa.

Y. M. Isa is with the Chemical Engineering Department of Durban University of Technology, Durban 4000, South Africa.
This form of contamination has become a serious issue of global concern due to its prevalence and the prolific threat posed on the sustainability of the ecosystem. Due to the constant demand for petroleum products, the exploration of crude oil to meet human demand becomes imperative, hence the possibility of soil contamination, and devising an eco-friendly remediation technique becomes a necessary evil. Previous methods of remediation of crude oil contaminated soils have some room for improvement to render effective treatment. However, these approaches have been criticized due to its expensive and non-eco-friendly nature which made site reclamation a difficult task [1], [2]. The use of biological methods which include bioattenuation, biostimulation, bioaugmentation, bioventing, and phytoremediation have offered the promising potential for the remediation of crude oil contaminated soils. Bioremediation provides the application of organic or inorganic nutrients (biostimulation), or injection of air or oxygen (bioventing) or the introduction of genetically modified strains or consortium (bioaugmentation) while phytoremediation involves the use of plants and/or associated microbes for the reduction of contaminant concentration in the environment to facilitate remediation [3-6]. The use of organic and inorganic substrates modifies the environment by introducing nutrients such as nitrogen, phosphorus and other electron acceptors to increase the rate of contaminant degradation under indigenous bacteria [7-12]. Bioventing provides oxygen which ventilates the contaminated environment to increase the rate of biodegradation. Recently, researchers focused on the use of oxygen released compounds and the supply of air to promote the oxidation of pollutants by activation of oxic conditions to enhance microbial activities for the contaminant remediation. Several studies by [13], [14] and [15] have proven the efficacy of air-injection for the remediation of crude oil contaminated soils.

Having reviewed relevant literature, this study aims to evaluate the application of wastewaters (brewery and municipal wastewater) and the combined effect of wastewaters and air-injection for the treatment of crude oil contaminated soils.

\section{MATERIALS AND METHOD}

\section{A. Materials}

Soil samples were collected from Durban, South Africa and air-dried for 24hours and subsequently passed through a standard sieve of $2 \mathrm{~mm}$ screen. Soil samples for the treatment 
were preserved in a polyethylene bag for future use. Crude oil was collected from Engen oil Refinery while Brewery and Municipal wastewaters were gotten from South African Brewery (SAB) and local South Africa wastewater plant respectively. Wastewaters were stored in HDPE containers, kept in the refrigerator. Brewery waste and Municipal waste were characterized for carbon-oxygen demand (COD) as shown in Table I.

\begin{tabular}{lcc}
\multicolumn{3}{c}{ TABLE I. BWW AND MWW PROPERTIES } \\
\hline $\begin{array}{l}\text { Wastewater/ } \\
\text { Composition }\end{array}$ & BWW & MWW \\
\hline COD (mg/l) & 750 & 704 \\
\hline $\mathrm{Ph}$ & 8.2 & 7.9 \\
\hline
\end{tabular}

\section{B. Methodological Approach}

\section{1) Simulation of crude oil contaminated soil}

The crude oil contaminated soils were prepared by spiking $1 \mathrm{~kg}$ of soil sample with crude oil with $50 \mathrm{~g}(5 \% \mathrm{w} / \mathrm{w})$ and agitated in a mechanical shaker to achieve an even distribution of crude oil in the contaminated soil. To achieve severe contamination of soil, 5\%(w/w) crude oil contamination was adopted [16]. The contaminated soil was allowed for 2 days for aging and to mimic a real scenario before the application of bioremediation methods.

\section{2) Bioremediation studies for Crude \\ oil-contaminated soil}

The treatment of contaminated soil was achieved through the application of biostimulation and bioventing (BVT) methods. The experimental setup for the Biostimulation and bioventing treatment treatments consists of five and four bioreactors respectively. Wastewaters (BWW and MWW) were amended at different ratios for the biostimulation study while atmospheric air was supplied to the bioventing system and amended with wastewaters as shown in Table II. Air was injected at $3 \mathrm{~L} / \mathrm{min}$ for 30 minutes every 48 hours air compressor (Fig. 1). The bioattenuation (BAT) which neither vented nor amended with wastewaters was used as a control treatment. All treatments were conducted at ambient temperature and samples collected from each treatment for total petroleum hydrocarbon (TPH) analysis.

TABLE II. BST AND BST TREATMENT OF CRUDE OIL-CONTAMINATED SOIL

\begin{tabular}{lcccc}
\hline Bioreactors & $\begin{array}{l}\text { BWW } \\
\left(\mathrm{mg} / \mathrm{kg}^{-1}\right. \\
\text { soil) }\end{array}$ & $\begin{array}{l}\mathrm{MWW} \\
\left(\mathrm{mg} / \mathrm{kg}^{-1}\right. \\
\text { soil) }\end{array}$ & $\begin{array}{l}\text { Air } \\
\left(\mathrm{O}_{2}\right)\end{array}$ & $\begin{array}{l}\text { Loading ratio } \\
\text { (BWW:MWW). }\end{array}$ \\
\hline BST-1 & 100 & 0 & - & $4: 0$ \\
\hline BST-2 & 75 & 25 & - & $3: 1$ \\
\hline BST-3 & 50 & 50 & - & $2: 2$ \\
\hline BST-4 & 25 & 75 & - & $1: 3$ \\
\hline BST-5 & 0 & 100 & - & $0: 4$ \\
\hline BVT-1 & 0 & 0 & $\checkmark$ & $0: 0$ \\
\hline BVT-2 & 100 & 0 & $\checkmark$ & $4: 0$ \\
\hline BVT-3 & 0 & 100 & $\checkmark$ & $0: 4$ \\
\hline BVT-4 & 50 & 50 & $\checkmark$ & $2: 2$ \\
\hline BAT & 0 & 0 & - & $0: 0$
\end{tabular}

Fig. 1. Schematic Diagram for the Bioventing (BVT) Treatment System

\section{Analytical Procedure \\ 1) Mechanical Extraction of Residue Crude oil}

Soil samples were dried, pulverized using pistol and mortar, and then passed through a standard sieve size of $63 \mu \mathrm{m}$ to ensure grains homogeneity. $5 \mathrm{~g}$ of homogenized soil sample was mixed with DCM acetone in a ratio of 2:1, agitated for $90 \mathrm{mins}$ at 200rpm in a mechanical shaker for effective extraction of residue crude oil. The extracted crude oil was filtered, and the filtrate was analyzed using GCMS for TPH. COD was determined through standard method using COD reactor (Hach) and Spectrophotometry (DR 3900) while an electronic $\mathrm{pH}$ meter was used to determine the $\mathrm{pH}$ of samples.

\section{RESUltS AND DISCUSSION}

\section{A. Biostimulation and Bioventing of Crude oil}

\section{Contaminated Soils - Results}

The results of the treatment showed that the amendment of wastewater for the biostimulation treatment facilitated the reduction in TPH concentration. The TPH removal was relatively fast for the first 2 weeks of BST treatment. However, BSTc-2, 3, and 4 observed similar trends in TPH reduction with respect to other treatments but recorded removal efficiencies of $48.67 \%, 49.67 \%$, and $48.81 \%$ respectively which corresponds to $>24000 \mathrm{mg} / \mathrm{kg}$ TPH removal in week 4 (Fig. 3). The average removal efficiency of $>15 \%$ was observed for these treatments (BST-2, 3, and 4) in week 1, but as BST-2 and BST-3 increased by average of $>7 \%$ in TPH removal efficiencies from week 2 to 3 , BST-4 only recorded $5.5 \%$ increase in removal efficiencies from week 2 to 3 while week 4 recorded $>5 \%$ average increase in removal efficiencies for BST-2 and BST-4, and <3\% increase for BSTc-3. The highest removal efficiency was recorded with BST-1 with $>7 \%$ increase in average removal efficiency from week 2 to attain $58.39 \%(29,195 \mathrm{mg} / \mathrm{kg}$ TPH removal) after 28 days while BST-5 removed $28,310 \mathrm{mg} / \mathrm{kg}$ which correspond to $56.62 \%$ removal efficiency (Fig. 3). The BVT treatment showed increased TPH reduction from week 1 with the introduction of atmospheric air which recorded a 
significant removal efficiency of $74.75 \%$ at $18.69 \%$ average increase for BVT-2 (from week 1 to week 4) to reduce TPH concentration to $12,625 \mathrm{mg} / \mathrm{kg}$ after week 4 (Fig. 4). However, BVT-3 and BVT-4 recorded an average increase of $15 \%$ in TPH removal efficiency (from week 1 to week 4) and were able to reduce TPH concentration to $19990 \mathrm{mg} / \mathrm{kg}$ and $19265 \mathrm{mg} / \mathrm{kg}$ from the treatment respectively in week 4 while BVT-1 maintained $>9 \%$ average increase in removal efficiencies to successfully remove $27465 \mathrm{mg} / \mathrm{kg}$ TPH from the treatment (Fig. 4). In comparison to other treatments, the control treatment BATc recorded the least removal efficiency (34.5\%) representing $17,250 \mathrm{mg} / \mathrm{kg}$ TPH removal from the treatment.

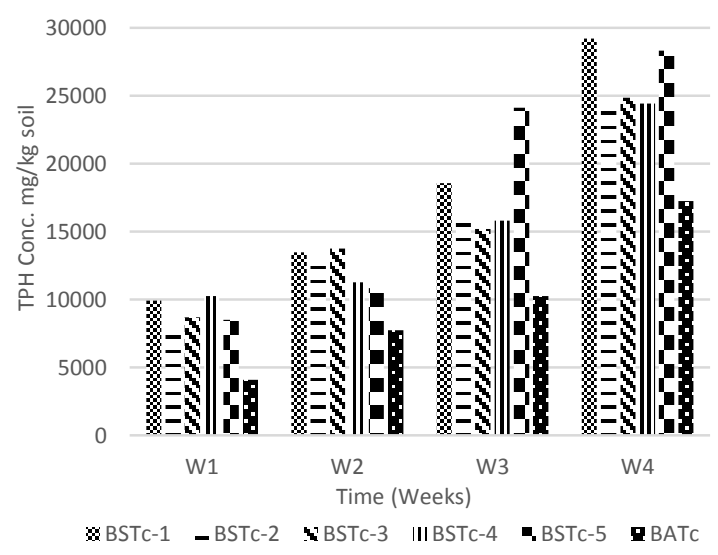

Fig. 2. TPH removal (mg/kg soil) from BST treatment

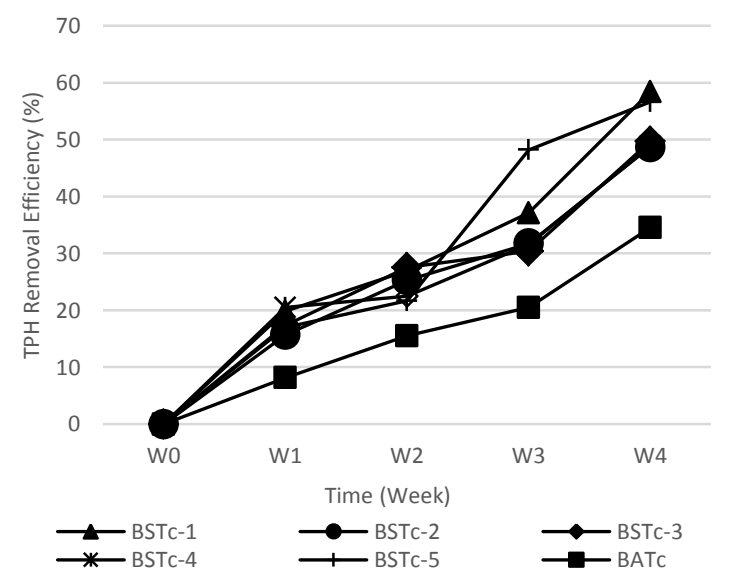

Fig. 3. Evaluation of TPH removal Efficiency of BST treatment

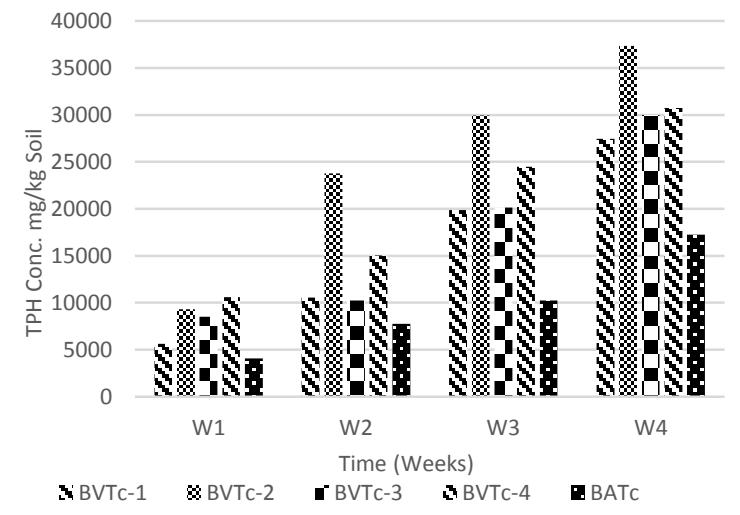

Fig. 4. TPH removal (mg/kg soil) from BVT treatment

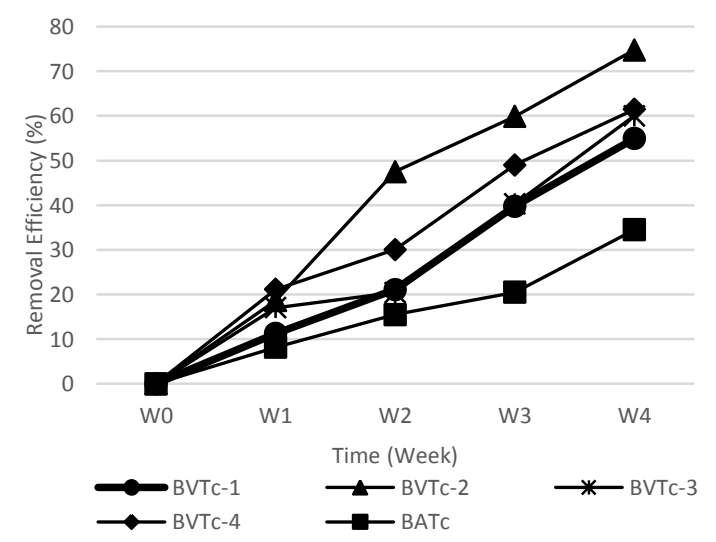

Fig. 5. Evaluation of TPH removal Efficiency of BVT treatment

\section{B. Discussion}

The amendment of wastewater for the BST treatment enhanced microbial activities as evident in the increase in TPH weekly removal efficiency from week 1 to week 4 indicates, since the introduction of the wastewater provides organic nutrients to the native microorganisms in the soil for an effective TPH degradation, and the correlation between microbial growth and increase in biodegradation has been validated in different studies [7-11]. Also, organic substrates like MWW and BWW act as bulking agents, $\mathrm{pH}$ buffer, organic replacement, soil conditioners and also a natural surfactant that improves petroleum solubility [17] to improve bioavailability and metabolism for the treatment of TPH polluted soils [12]. Reference [18] reported that the use of organic nutrient also serves to immobilize oil-degrading strains which consume these substrates and transform them into usable biomass for hydrogenase. However, the appreciable TPH removal efficiency of $58.39 \%$ recorded by treatments amended with BWW (BST-1) when compared to BST-5 (MWW) (56.62\%) can be attributed to the high nutrient content present in brewery wastewater which accounts for the substantial microbial load in BWW [18-22], required for enhanced biodegradation of crude oil [18]. This also explains the slight variation in the removal efficiencies recorded with the mixed substrates (BST-2, $3 \& 4$ ) with an average removal efficiency of $49.05 \%$.

The introduction of air into the bioventing system, however, improved oxic conditions for the BVT treatments, by creating an aerobic atmosphere which is responsible for the reinforcement of autochthonous microorganisms' activities 
[23]. The application of combined air-injection and nutrient amendment enhance TPH removal efficiency according to [13] than the single application of these techniques, as the presence of oxygen ventilates the environment, wastewater ensures the availability of nutrients [7] to the degrading organisms, which accounts for the significant biodegradation efficiency recorded with BVT treatments. From the results of this study, the introduction of atmospheric air (BVT treatments) increased the TPH removal efficiencies by $16.36 \%, 3.4 \%$ and $12.42 \%$ (BVT-2 (air + BWW), BVT-3 (air + MWW) and BVT-4 (air + BWW + MWW) respectively) which represents $74.75 \%$, $60.02 \%$ and $61.47 \%$ when compared to corresponding BST treatments (BST-1 (BWW). BST-5 (MWW) and BST (BWW + MWW) respectively). Also, the average removal efficiency of BVT treatment was $10.36 \%$ greater than the BST treatment $(52.43 \%)$. The findings of this study, validated by [24], [15] and [25] were in clear contrast to those of [26], which reported that nutrient amendment to BVT treatment was insignificant for increased biodegradation efficiency. Moreover, it has been reported that some nutrients and soil type may be a limiting factor in biodegradation since some additives may trigger increased toxicity [14] and soil type (i.e. clay soil) can result to low oxygen penetration due to small pores which possibly reduce TPH removal efficiency [27-30], hence, may justify the findings by [26].

In agreement with the current BST study which recorded $52.43 \%$ average removal efficiency after 28 days, [31] recorded $43 \%$ using an organic substrate with $60,000 \mathrm{mg} / \mathrm{kg}$ while 3000 and $30,000 \mathrm{mg} / \mathrm{kg}$ contaminated soil recorded $52.11 \%$ and $58.36 \%$ average removal efficiencies after 90days study period. The findings showed that crude oil concentration above $30,000 \mathrm{mg} / \mathrm{kg}$ lowers TPH biodegradation efficiency which applies to the present study. Similarly, [32] and [33] recorded $45-65.6 \%$, and $45-60 \%$ (average of $55.3 \%$, and $52.5 \%$ ) removal efficiencies using sewage sludge after 9 and 10 weeks study period respectively which corresponds to the results of the present BST study (48-58\% removal efficiency). However, the results of the current BVT study with $54.93 \%$ (BVT) and $65.41 \%$ (BVT and wastewater amendment) average TPH removal efficiencies correspond to the studies by [34] and [7] which reported $64.2 \%$ and $61.7 \%$ TPH removal efficiencies with bioventing after 12 month and 28 days treatment period respectively while and appreciable removal efficiency of $>75 \%$ was recorded with bioventing and organic amendment according to [7] after 28 days. Similarly, [13], [14] and [15] recorded $>70 \% \mathrm{TPH}$ removal with bioventing and nutrient amendment technique after 112, 210 and 120days treatment period accordingly while [35] and [36] reported an average of $60 \%$ and $65 \%$ TPH removal efficiencies with bioventing and nutrient supplement after 91 and 40-50days study period respectively. The study showed that wastewater can serve an effective organic stimulant while air-injection adequately provides an aerobic environment for appreciable TPH reduction and treatment of crude oil contaminated soils.

\section{CONCLUSION}

It can be deduced from this study that the application of wastewater as an organic substrate can stimulate the microbial environment to promote biodegradation while air-injection provided enough oxygen in the treatment system which enhanced aerobic conditions for effective biodegradation and TPH removal. The combined applications of BVT and wastewater amendment was more effective as evident in the significant removal efficiency of $65.41 \%$ (avg.) while bioventing and biostimulation recorded $52.43 \%$ and $54.93 \%$ average TPH removal efficiencies respectively. However, further study is required to validate the large scale application of this method.

\section{REFERENCES}

[1] J. W. J. Rojas, N. C. Consoli, and K. S. Heineck, "Treatment of contaminated soil: Encapsulation analysis of heavy metals," Estudos Tecnológicos em Engenharia, vol. 5, no. 1, pp. 79-88, 2009. https://doi.org/10.4013/ete.2009.51.06

[2] J. E. Vidonish, K. Zygourakis, C. A. Masiello, G. Sabadell, and P. J. J. Alvarez, "Thermal Treatment of Hydrocarbon-Impacted Soils: A Review of Technology Innovation for Sustainable Remediation," Engineering, vol. 2, no. 4, pp. 426-437, 2016/12/01/ 2016. https://doi.org/10.1016/J.ENG.2016.04.005

[3] C. C. Azubuike, C. B. Chikere, and G. C. Okpokwasili, "Bioremediation techniques-classification based on site of application: principles, advantages, limitations and prospects," World Journal of Microbiology and Biotechnology, vol. 32, no. 11, p. 180, 2016. https://doi.org/10.1007/s11274-016-2137-x

[4] A. A. Juwarkar, S. K. Singh, and A. Mudhoo, "A comprehensive overview of elements in bioremediation," Reviews in Environmental Science and bio/technology, vol. 9, no. 3, pp. 215-288, 2010. https://doi.org/10.1007/s11157-010-9215-6

[5] M. Leung, "Bioremediation: techniques for cleaning up a mess," BioTeach Journal, vol. 2, pp. 18-22, 2004.

[6] B. Thapa, A. K. Kc, and A. Ghimire, "A review on bioremediation of petroleum hydrocarbon contaminants in soil," Kathmandu university journal of science, engineering and technology, vol. 8, no. 1, pp. 164-170, 2012.

https://doi.org/10.3126/kuset.v8i1.6056

[7] S. Agarry and G. Latinwo, "Biodegradation of Diesel Oil in Soil and Its Enhancement by Application of Bioventing and Amendment with Brewery Waste Effluents as Biostimulation-Bioaugmentation Agents," Journal of Ecological Engineering, vol. 16, pp. 82-91, 2015. https://doi.org/10.12911/22998993/1861

[8] C. C. Chijioke-Osuji, P. N. Ibegbulam-Njoku, and E. J. Belford, "Biodegradation of crude oil polluted soil by Co-composting with agricultural wastes and inorganic fertilizer," Biodegradation, vol. 4, no. 6, 2014.

https://doi.org/10.9734/BMRJ/2014/12008

[9] C. B. Chikere, K. Surridge, G. C. Okpokwasili, and T. E. Cloete, "Dynamics of indigenous bacterial communities associated with crude oil degradation in soil microcosms during nutrient-enhanced bioremediation," Waste Manag Res, vol. 30, no. 3, pp. 225-36, Mar 2012. https://doi.org/10.1177/0734242X11410114

[10] L. Mao and Q. Yue, "Remediation of diesel-contaminated soil by bioventing and composting technology," in 2010 International Conference on Challenges in Environmental Science and Computer Engineering, 2010, vol. 2, pp. 3-6: IEEE. https://doi.org/10.1109/CESCE.2010.224

[11] R. U. Ofoegbu, Y. O. L. Momoh, and I. L. Nwaogazie, "Bioremediation of Crude Oil Contaminated Soil Using Organic and Inorganic Fertilizers," Journal of Petroleum \& Environmental Biotechnology, vol. 6:198, 2014. https://doi.org/10.4172/2157-7463.1000198

[12] F. V. Adams, A. Niyomugabo, and O. P. Sylvester, "Bioremediation of Crude Oil Contaminated Soil Using Agricultural Wastes," Procedia Manufacturing, vol. 7, pp. 459-464, 2017/01/01/ 2017. https://doi.org/10.1016/j.promfg.2016.12.037

[13] A. Thomé, C. Reginatto, I. Cecchin, and L. M. Colla, "Bioventing in a residual clayey soil contaminated with a blend of biodiesel and diesel oil," Journal of Environmental Engineering, vol. 140, no. 11, p. 06014005, 2014. https://doi.org/10.1061/(ASCE)EE.1943-7870.0000863

[14] F. J. G. Frutos, O. Escolano, S. García, M. Babín, and M. D. Fernández, "Bioventing remediation and ecotoxicity evaluation of 
phenanthrene-contaminated soil," Journal of hazardous materials, vol. 183, no. 1-3, pp. 806-813, 2010.

https://doi.org/10.1016/j.jhazmat.2010.07.098

[15] J. Møller, P. Winther, B. Lund, K. Kirkebjerg, and P. Westermann, "Bioventing of diesel oil-contaminated soil: comparison of degradation rates in soil based on actual oil concentration and on respirometric data," Journal of Industrial Microbiology, vol. 16, no. 2, pp. 110-116, 1996. https://doi.org/10.1007/BF01570070

[16] L. Osuji, E. Egbuson, and C. Ojinnaka, "Chemical reclamation of crude-oil-inundated soils from Niger Delta, Nigeria," Chemistry and Ecology, vol. 21, no. 1, pp. 1-10, 2005. https://doi.org/10.1080/02757540412331335988

[17] Q. Liu et al., "Bioremediation of petroleum-contaminated soil using aged refuse from landfills," (in eng), Waste Manag, vol. 77, pp. 576-585, Jul 2018. https://doi.org/10.1016/j.wasman.2018.05.010

[18] D. K. Amenorfenyo et al., "Microalgae Brewery Wastewater Treatment: Potentials, Benefits and the Challenges," International journal of environmental research and public health, vol. 16, no. 11, p. 1910, 2019. https://doi.org/10.3390/ijerph16111910

[19] J. Bwapwa, A. Jaiyeola, and R. Chetty, Bioremediation of acid mine drainage using algae strains: A review. 2017. https://doi.org/10.1016/j.sajce.2017.06.005

[20] A. Gebeyehu, N. Shebeshe, H. Kloos, and S. Belay, "Suitability of nutrients removal from brewery wastewater using a hydroponic technology with Typha latifolia," BMC Biotechnology, vol. 18, no. 1, p. $74,2018 / 11 / 222018$. https://doi.org/10.1186/s12896-018-0484-4

[21] A. T. Jaiyeola and J. K. Bwapwa, "Treatment technology for brewery wastewater in a water-scarce country: a review," South African journal of science, vol. 112, no. 3-4, pp. 1-8, 2016. https://doi.org/10.17159/sajs.2016/20150069

[22] T. B. Kebede, "Wastewater treatment in brewery industry, review," International Journal of Engineering Development and Research 6 (1), pp. 2321-9939, 2018.

[23] N. Couto and F. J. García-Frutos, "Biological Techniques to Remediate Petroleum Hydrocarbons in Contaminated Environments," Soil Remediation: Applications and New Technologies, p. 139, 2016. https://doi.org/10.1201/b19916-10

[24] M. D. Lee and C. M. Swindoll, "Bioventing for in situ remediation," Hydrological sciences journal, vol. 38, no. 4, pp. 273-282, 1993. https://doi.org/10.1080/02626669309492674

[25] L. T. Bulman, M. Newland, and A. Wester, "In situ bioventing of a diesel fuel spill," Hydrological Sciences Journal, vol. 38, pp. 297-308, 1993. https://doi.org/10.1080/02626669309492676

[26] R. R. Dupont, W. J. Doucette, and R. E. Hinchee, "Assessment of in situ bioremediation potential and the application of bioventing at a fuel-contaminated site," in In situ bioreclamation, 1991. https://doi.org/10.1016/B978-0-7506-9301-1.50019-6

[27] P. B. Dorn and J. P. Salanitro, "Temporal ecological assessment of oil contaminated soils before and after bioremediation," Chemosphere, vol. 40, no. 4, pp. 419-426, 2000. https://doi.org/10.1016/S0045-6535(99)00304-5

[28] A. Haghollahi, M. H. Fazaelipoor, and M. Schaffie, "The effect of soil type on the bioremediation of petroleum contaminated soils," Journal of environmental management, vol. 180, pp. 197-201, 2016. https://doi.org/10.1016/j.jenvman.2016.05.038

[29] C. K. Kwok and K. C. Loh, "Effects of Singapore soil type on bioavailability of nutrients in soil bioremediation," Advances in Environmental Research, vol. 7, no. 4, pp. 889-900, 2003. https://doi.org/10.1016/S1093-0191(02)00084-9

[30] Q. Lin et al., "Effects of bioremediation agents on oil degradation in mineral and sandy salt marsh sediments," Environmental technology, vol. 20, no. 8, pp. 825-837, 1999. https://doi.org/10.1080/09593332008616878

[31] L. Mohajeri, M. A. Zahed, H. Abdul Aziz, and M. Hasnain Isa, "Assessment of Bioaugmentation and Biostimulation Efficiencies for Petroleum Contaminated Sediments," Environmental Energy and Economic Research, vol. 1, no. 1, pp. 89-98, 2017.

[32] C. C. Ling and M. H. Isa, "Bioremediation of oil sludge contaminated soil by co-composting with sewage sludge.," journal of Scientific and Industrial Research, vol. 65(04), pp. pp. 364-369, 2006.

[33] M. Chorom, S. Hosseini, and H. Motamedi, "Bioremediation of crude oil polluted soil as affected by sewage-sludge," in Proceedings of the 19th World Congress of Soil Science: Soil solutions for a changing world,
Brisbane, Australia, 1-6 August 2010. Symposium 3.5. 2 Risk assessment and risk based remediation, 2010, pp. 4-7: International Union of Soil Sciences (IUSS), c/o Institut für Bodenforschung ....

[34] M. Balba, R. Al-Daher, N. Al-Awadhi, H. Chino, and H. Tsuji, "Bioremediation of oil-contaminated desert soil: the Kuwaiti experience," Environment International, vol. 24, no. 1-2, pp. 163-173, 1998. https://doi.org/10.1016/S0160-4120(97)00132-3

[35] J. Jia et al., "Removal Efficiency and the Mineralization Mechanism During Enhanced Bioventing Remediation of Oil-Contaminated Soils," Polish Journal of Environmental Studies, vol. 25, no. 5, 2016. https://doi.org/10.15244/pjoes/63411

[36] E. Eslami and S. H. S. Joodat, "Bioremediation of oil and heavy metal contaminated soil in construction sites: a case study of using bioventing-biosparging and phytoextraction techniques," arXiv preprint arXiv:1806.03717, 2018.

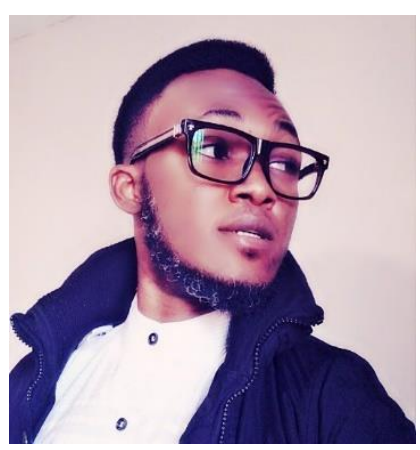

Ifeanyi M. Anekwe was born in $20^{\text {th }}$ April at Anambra state, located in the south-eastern part of Nigeria where he obtained his first degree in Petroleum Engineering (BEng.) from Federal University of Technology, Owerri, Imo State, Nigeria in 2011. In 2013, he bagged a professional proficiency certificate in management from the Nigerian Institute of Management (NIM-Chartered) and was inducted as a member of the Institute. Anekwe is an MEng candidate of Chemical Engineering at Durban University of

\section{Technology, South Africa,}

He's currently a TUTOR in the Chemical Engineering Department at the Faculty of Engineering and the Built Environment, DUT. He has contributed to the following publication: Water treated promoted catalysts for the conversion of ethanol to hydrocarbons: Y. M Isa, U. A. Mohammed, R. Musamali, and I. M. Anekwe. Proceedings of the International Conference on Sustainable Energy-Water-Environment Nexus 2019. (ACCEPTED).

His research interest includes enhanced oil recovery (EOR), bioremediation technology, environmental sustainability, Desalination, acid mine drainage (AMD), and crude oil pollution remediation. 